\title{
1 A rapid, sensitive, scalable method for Precision Run-On sequencing (PRO-seq)
}

7 Leighton J. Core ${ }^{2 \dagger}$

*Equal contribution

1Department of Molecular Biology and Genetics, Cornell University, Ithaca, NY 14853, USA 2Department of Molecular and Cell Biology, Institute of Systems Genomics, University of Connecticut, Storrs, CT 06269, USA ${ }^{3}$ Baker Institute for Animal Health, College of Veterinary Medicine, Cornell University, Ithaca, 14 NY 14853, USA

$15{ }^{4}$ Department of Biomedical Sciences, College of Veterinary Medicine, Cornell University, 16 Ithaca, NY 14853, USA

17 \#apresent address: Koch Institute for Integrative Cancer Research, Massachusetts Institute of 18 Technology, Cambridge, MA 02139, USA

19 \#bresent address: Department of Genome Sciences, University of Washington, Seattle, WA, 20 USA

21 TCorrespondence to: leighton.core@uconn.edu or johnlis@cornell.edu 


\section{Abstract}

Tracking active transcription with the nuclear run-on (NRO) assays has been instrumental in uncovering mechanisms of gene regulation. The coupling of NROs with high-throughput

27 sequencing has facilitated the discovery of previously unannotated or undetectable RNA classes

28 genome-wide. Precision run-on sequencing (PRO-seq) is a run-on variant that maps polymerase active sites with nucleotide or near-nucleotide resolution. One main drawback to this and many other nascent RNA detection methods is the somewhat intimidating multi-day workflow associated with creating the libraries suitable for high-throughput sequencing. Here, we present an improved PRO-seq protocol where many of the enzymatic steps are carried out while the biotinylated NRO RNA remains bound to streptavidin-coated magnetic beads. These adaptations reduce time, sample loss and RNA degradation, and we demonstrate that the resulting libraries are of the same quality as libraries generated using the original published protocol. The assay is also more sensitive which permits reproducible, high-quality libraries from $10^{4}-10^{5}$ cells instead of $10^{6}-10^{7}$. Altogether, the improved protocol is more tractable allows for nascent RNA profiling from small samples, such as rare samples or FACS sorted cell populations.

Keywords: Nuclear run-on, Nascent RNA, Transcription, RNA polymerase, non-coding RNA 


\section{Introduction}

Next-generation sequencing technologies are now routinely used to measure gene expression levels in a highly sensitive and comprehensive fashion. RNA-seq facilitate simultaneous detection, identification, and annotation of many classes of cellular RNAs. Traditionally, however, this technology primarily measures steady-state RNA levels, which are a consequence of equilibrium between RNA transcription, processing, and degradation. As a result, many unstable RNAs, particularly eRNA and some IncRNAs, are not easily detected with these approaches. Alternatively, ChIP-seq allows for identification and quantification of RNA polymerase II (Pol II) associated DNA. This produces a genome-wide map of both transcriptionally active and inactive Pol II without strand specificity, thus the direction and transcriptional status of the polymerase are ambiguous. Furthermore, the relatively high background in ChIP-seq as compared to RNA-based methods obfuscates comprehensive transcript and regulatory element detection. To address these shortcomings, various methods of measuring transcription by genome-wide profiling of nascent RNA have now been developed including GRO-seq (Core et al., 2008), PRO-seq (Kwak et al., 2013), NET-seq (Churchman and Weissman, 2011), and TT-seq (Schwalb et al., 2016). Characteristics of these assays are reviewed in (Wissink et al., 2019).

GRO-seq and PRO-seq are modern, genome-wide improvements of the nuclear run-on assay, which has been in use for approximately 60 years (Weiss and Gladstone, 1959). Over the years, run-on assays have been instrumental in the study or discovery of various forms of gene regulation including, steady state transcription levels and mRNA turnover (Derman et al., 1981; Powell et al., 1984), promoter-proximal pausing (Gariglio et al., 1981; Rougvie and Lis, 1988), transcription rates (Bentley and Groudine, 1986; Hirayoshi and Lis, 1999; O'Brien and Lis, 1993), and 3'-end processing and termination (Birse et al., 1997). The nuclear run-on reaction works by adding labelled nucleotides to polymerases that are halted in the act of transcription yet still transcriptionally competent. The polymerases incorporate the exogenous NTPs and the labelled nascent transcripts can then be detected and quantified. In 2004, the assay was adapted for macro-array by spotting probes of whole yeast genes on to nylon membranes (García-Martínez et al., 2004). In 2008, the nuclear run-on assay was expanded to cover the entire genome in global run-on and sequencing (GRO-seq) (Core et al., 2008). GRO- 
81 seq employs a BrU-containing run-on reaction, enabling affinity purification

\section{8; Kwak, 2013) have now been used to study the transcriptional}
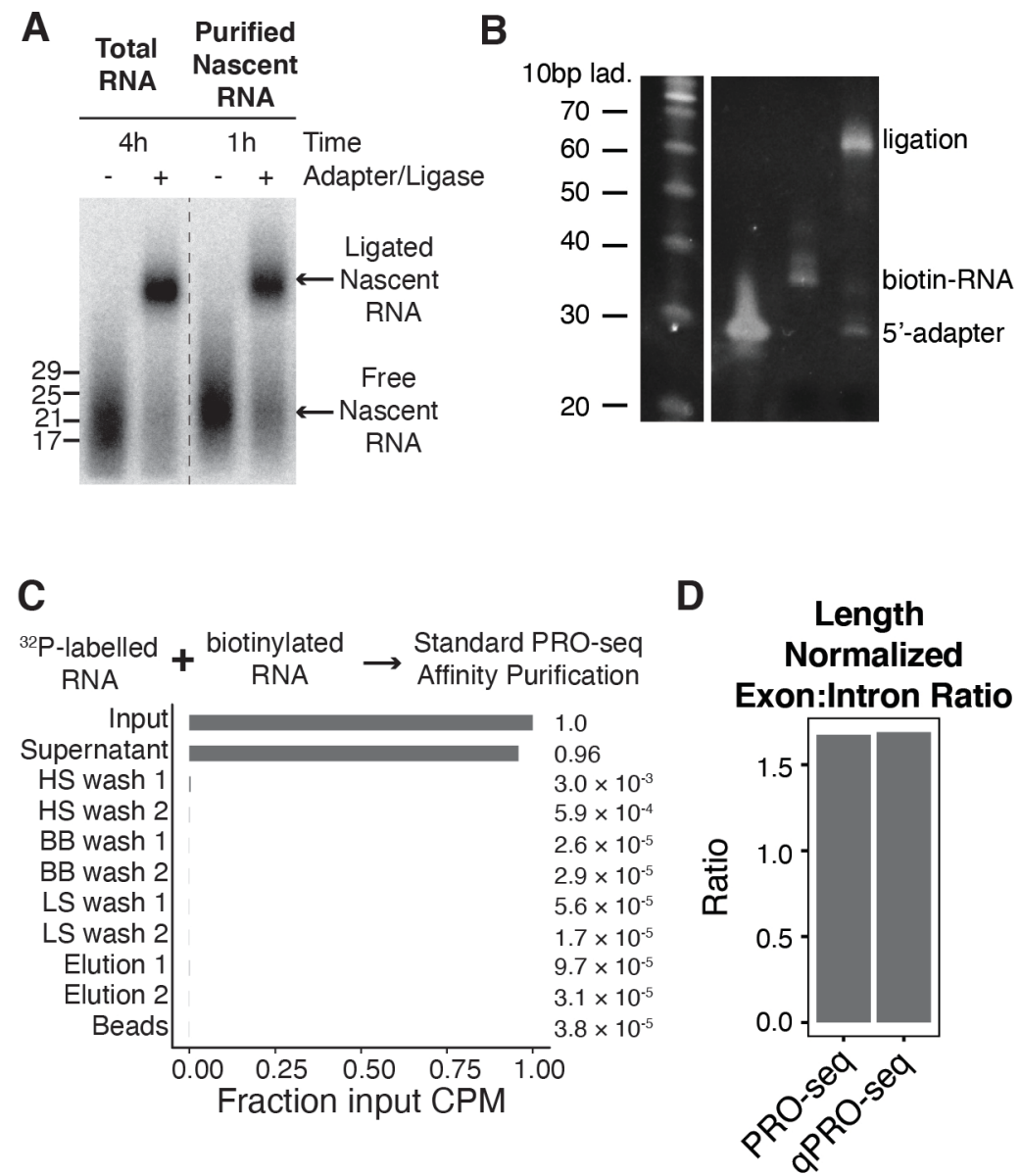

Figure 2: Validation of key enzymatic steps. (A) Ligation of the $3^{\prime}$ adapter in hydrolyzed total RNA vs. purified nascent RNA. ${ }^{32} \mathrm{P}$ labelled nascent RNA was ligated for $1 \mathrm{~h}$ using the ligation conditions in this protocol or using the standard PRO-seq ligation conditions in (Mahat et al., 2016). (B) Efficiency of ligation to synthetic biotinylated RNA in 15\% PEG8000 (C) Stringency of biotin-RNA affinity purification with MyOne C1 Streptavidin beads. Excess ${ }^{32} \mathrm{P}$ labelled non-biotinylated RNA was mixed with biotinylated RNA, and CPM of each fraction was assessed using liquid scintillation counting. (D) PRO-seq and qPRO-seq show similar levels of exonic reads relative to intronic reads genomewide. kinetics of the heat-shock response in human (Vihervaara et al., 2017), mouse (Mahat et al., 2016), and fly (Duarte et al., 2016), for de novo discovery of promoters and enhancers in cells and tissues (Chu et al., 2018; Danko et al., 2015; Kruesi et al., 2013; Kwak, 2013; Wang et al., 2019), for transcription rate detection (Danko et al., 2013; Jonkers et al., 2014), and detection of RNA stability (Blumberg et al., 2019; Core et al., 2014).

The current, published PRO-seq protocol (Mahat et al., 2016) is undoubtedly time consuming, technically challenging, and requires significant amounts of starting material (0.5-2 $x 10^{7}$ cells). This is largely due to multiple streptavidin bead binding and subsequent elution steps (Fig. 1A), which require technical finesse with phenol:chloroform extraction and ethanol 
precipitation of nucleic acids and present repeated opportunity for loss of material. This has limited the adoption of PRO-seq by inexperienced laboratories and impeded studies of transcription in experimental systems that utilize rare or precious biological samples.

To address these shortcomings, we optimized the PRO-seq protocol to simplify library preparation and facilitate use of scarce input material in an improved protocol deemed qPROseq (quick Precision Run-On and sequencing; Fig. 1). The original protocol requires 4-5 working days to complete, and included three bead binding steps, and five phenol:chlofororm extractions and ethanol precipitations. By performing 3' adapter ligation to hydrolyzed total RNA instead of affinity purified nascent RNA, we eliminated one bead-binding step. We have validated that this ligation reaction is equally efficient to the standard PRO-seq ligation to purified nascent RNA (Fig. 2A). Downstream enzymatic reactions are then performed while nascent RNA is affixed to streptavidin beads (Fig. 2B), which eliminates another bead-binding step. On-bead reactions are performed in $2 \mathrm{X}$ volume to aid in handling, and simple bead washing steps replace numerous phenol:chloroform extractions and ethanol precipitations. The resulting single bead-binding protocol is much faster and easier than the original PRO-seq protocol (Fig. 1). It is feasible to start from permeabilized cells and end with adapter ligated cDNA in a single day ( 10 h; Fig. 1B). Furthermore, an option for column-based purification of RNA after the run-on reaction can eliminate another organic extraction step. Reverse transcription can be performed on beads, which completely eliminates organic extraction from the protocol, albeit with reduced efficiency.

In theory, reducing the number of affinity purifications and ligating adapters to bulk RNAs could reduce the specificity of the assay for nascent RNA. However, we have found that MyOne Streptavidin $\mathrm{C} 1$ beads, which have higher binding capacity per substrate area and are negatively charged to repel non-specific nucleic acid binding, sufficiently enrich nascent RNA over other cellular RNAs (Fig. 2C). Importantly, if nascent RNA was contaminated with mRNA, the number of reads mapping within exons would increase relative to reads mapping within introns. However, when we compared the length-normalized ratio of exonic reads to intronic reads, we observed no detectable difference between the original protocol and the improved protocol presented here (Fig. 2D).

Additional protocol changes have further simplified and improved the protocol. Careful titration of adapters eliminates the need for PAGE purification (Fig. 3A-B), which is difficult and time intensive and can introduce insert-size bias in the final libraries. Incorporation of a dual-UMI strategy reduces concern about PCR-duplicate reads. Furthermore, this eliminates the need for time-consuming test-amplification, except as an initial troubleshooting step when establishing the assay in a new cell type or with a new amount of input material. 


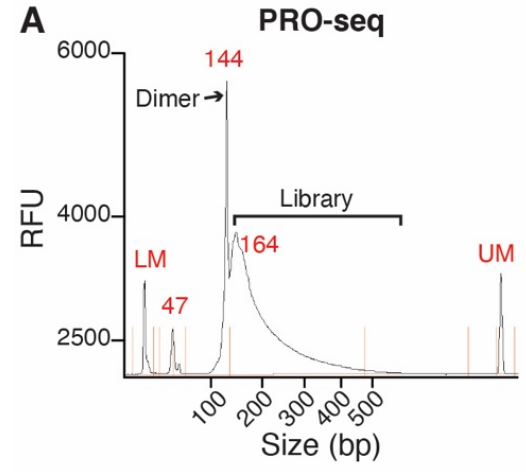

D

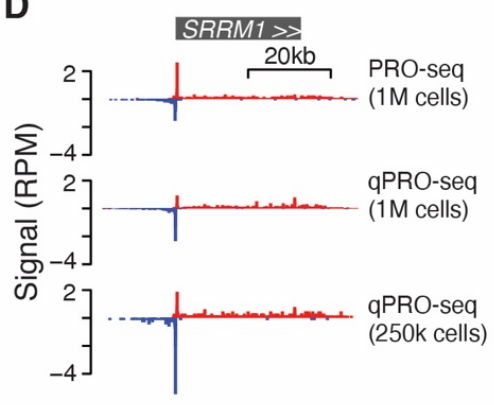

B

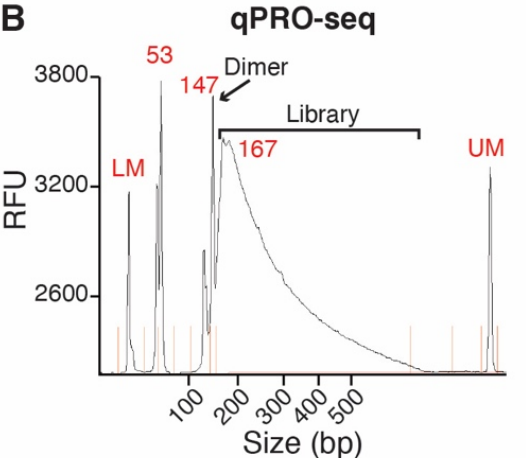

E

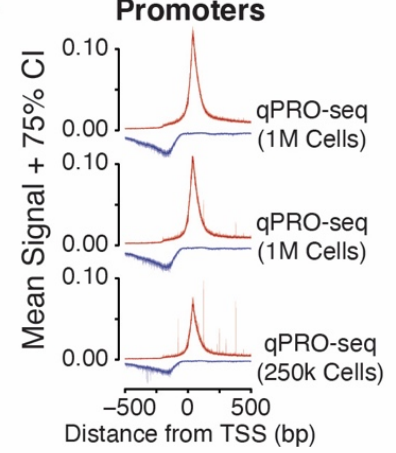

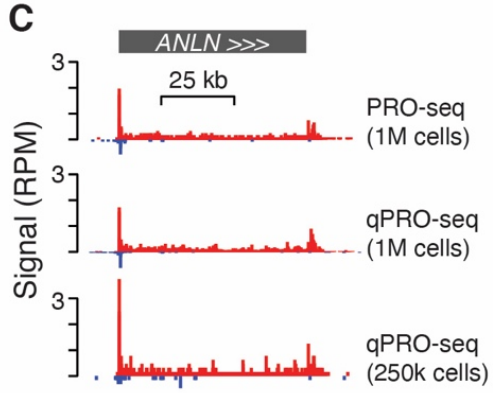

F

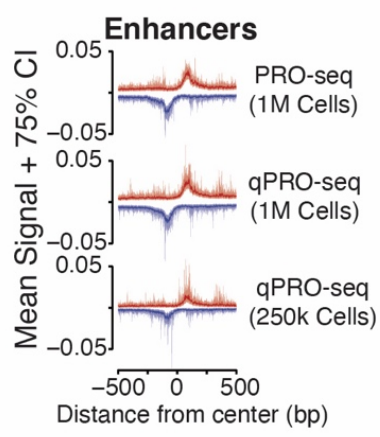

G
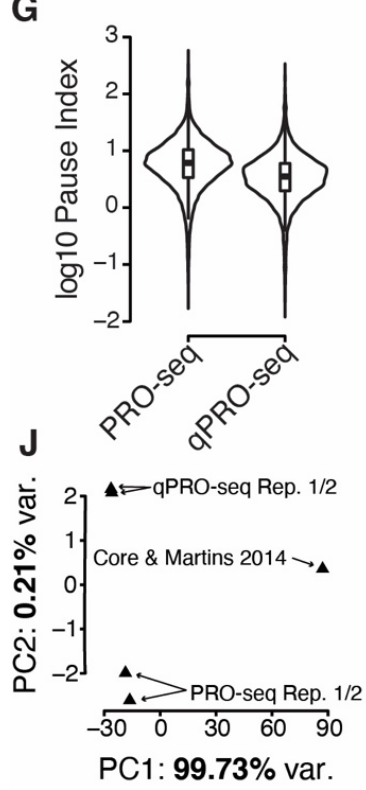

H

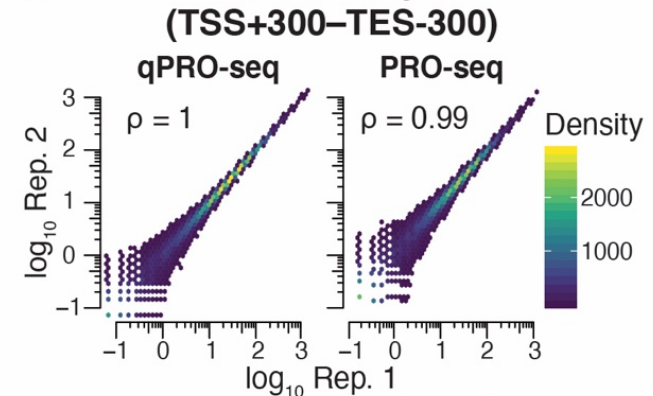

Rep. 1

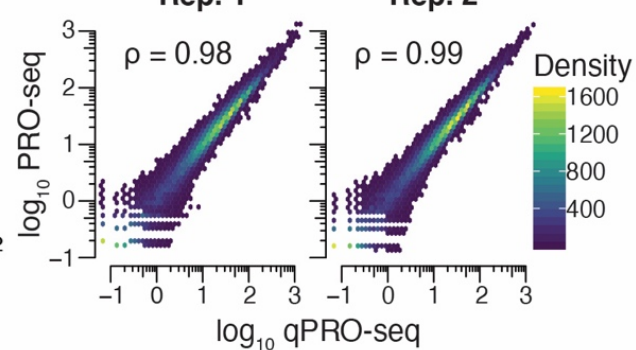

Rep. 2
I

Promoter

(TSS-200-TSS+300) qPRO-seq . PRO-seq

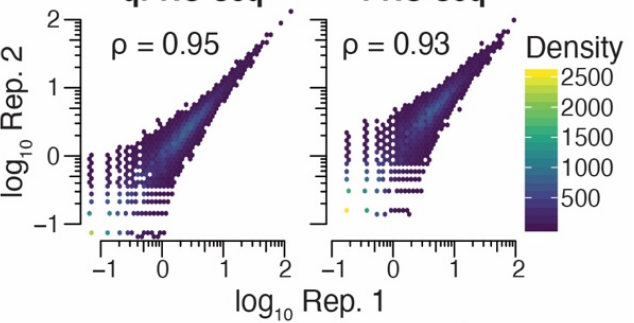

Rep. 1

Rep. 2

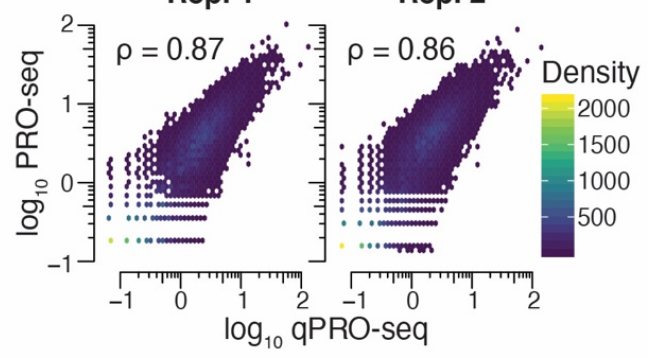

Figure 3: Direct comparison of PRO-seq and qPRO-seq in K562 cells. Bioanalyzer traces of libraries made using PRO-seq (A) and qPRO-seq. Library and adapter dimer are highlighed. (B). Browser shots showing readsper-million (RPM) normalized signal for PRO-seq (1M cells), qPRO-seq (1M cells), and qPRO-seq (250k cells) at $A N L N(C)$ and SRRM1 (D). Metaprofiles of signal at promoters (E) and enhancers (F). Mean and $75 \%$ confidence intervals are derived from 1000 subsamplings of $10 \%$ of regions. Enhancers are dREG peaks $>10 \mathrm{~kb}$ from a promoter. (G) Distribution of pause indicies at all genes in PRO-seq compared to qPRO-seq. (H) Correlation of RPM in gene body regions (TSS+300 to TES-300) between replicates and between protocols. (I) Correlation of RPM in promoter regions (TSS-200 to TSS+300) between replicates and between protocols. (J) Principal component analysis of PRO-seq, qPRO-seq, and published PRO-seq (Core et al. 2014) data in K562 cells. Variance explained (\%) by each component is noted on the axis. 
158

We have found that $10^{6}$ cells are sufficient input material for this new protocol, and that it can even be performed with as few as $0.05-0.25 \times 10^{6}$ cells (Fig 3C-F). Data quality typically increases up to $10^{6}$ cells but much smaller improvements are seen by further increasing cell number. Polymerases are sampled from fewer positions overall in libraries made with $0.25 \times 10^{6}$ cells, which causes data to look "spiky" and inflates read counts at highly expressed genes when normalizing per million mapped reads (Fig. 3C-F). Cell numbers required for high quality library generation will vary with the transcription activity of each cell type, with fast-dividing cultured cells typically showing the greatest activity.

We performed the new qPRO-seq protocol alongside the original protocol in two biological replicates of $10^{6} \mathrm{~K} 562$ cells (Fig. 3). We observe that the $\mathrm{C} 1$ beads decrease the bias against long RNAs seen with M280 beads, resulting in a relatively higher capture rate of gene body reads which results in lower overall pause indices (pause index is pause region signal divided by length-normalized gene body signal, so increased gene-body capture rate and unchanged pause region capture rate decreases pause index; Fig. 3G). In aggregate profiles, we observe no detectable difference in promoter or enhancer profiles across protocols (Fig. 3E-F). Though the overall number of unique reads obtained are lower in libraries made with $0.25 \times 10^{6}$ cells as is expected with scarce input material, we still observe transcription at many enhancers (Fig. $3 \mathrm{~F})$. We find that both assays can reproducibly quantify both gene body and promoter-proximal polymerases (Fig. $3 \mathrm{H}-\mathrm{I}$ ) and discover similar sets of regulatory elements using dREG (Wang et al., 2019). The promoter region is more inherently variable, but using principal component analysis, we were able to determine that when compared to published, deeply sequenced PROseq data in K562 cells (Core et al., 2014), batch effect and/or sequencing depth accounted for $>99 \%$ of variance in both the gene body and promoter region, while choice of protocol (PROseq or qPRO-seq) accounted for less than $0.3 \%$ of variance (Fig. $3 \mathrm{~J}$ ). This improved and optimized protocol expands the utility and accessibly of PRO-seq without sacrificing precision or data quality.

\section{Data Availability}

K562 PRO-seq and qPRO-seq raw sequencing data, processed bigWig files and dREG peaks files have been deposited in GEO (GSE150625).

\section{Code Availability}

Code used to analyze data and generate figures in this manuscript is available at https://github.com/JAJ256/qPRO. The pipeline used for PRO-seq alignment and processing is available at https://github.com/JAJ256/PROseq alignment.sh. "Browser shots" were generated using code found here: https://github.com/JAJ256/browser plot.R. 


\section{Author Contributions}

197 J.J. performed PRO-seq and qPRO-seq experiments and analyzed data. J.J., L.J.C., L.M.W, 198 and L.A.W wrote and revised the manuscript. L.A.W., L.M.W., G.J.V., and A.D. optimized on199 bead steps biochemical steps. All authors reviewed and approved the final manuscript. E.J.R. 200 contributed the qPCR protocol. E.M.W. performed experiments to optimize the protocol for low201 input experiments. All authors contributed experimentally or conceptually to the development of 202 this protocol.

203

204 Protocol Availability

205 The protocol presented in this manuscript is also available at

206 https://dx.doi.org/10.17504/protocols.io.57dg9i6 and will be updated as further improvements 207 are made.

\section{Acknowledgements}

210 We thank the Cornell BRC Genomics facility and Peter Schweitzer for assistance with Illumina 211 sequencing. We acknowledge many colleagues who have now used PRO-seq for various 212 applications that we did not cite in this manuscript due to space constraints. This work was 213 supported by NIH grants R01-GM025232 (to J.T.L.), R21-HG009021 and R35-GM128857 (to 214 L.J.C.), and R01-HG009309 (to C.G.D). J.J. was supported by NHGRI fellowship F31215 HG010820. The content is solely the responsibility of the authors and does not necessarily 216 represent the official views of the National Institutes of Health. 


\section{Materials}

! CRITICAL: Care should be taken to avoid nuclease contamination. Change gloves routinely and prepare/use nuclease-free reagents.

\subsection{Chemicals and Reagents}

1. Diethyl pyrocarbonate (DEPC; Sigma-Aldrich, cat. no. D5758) ! CAUTION: DEPC is toxic and harmful

2. DEPC treated $\mathrm{ddH}_{2} \mathrm{O}(0.1 \% \mathrm{v} / \mathrm{v})$

3. $4 \mathrm{M} \mathrm{KCl}$ (see Note 1)

4. $5 \mathrm{M} \mathrm{NaCl}$ (see Note 1)

5. $1 \mathrm{M} \mathrm{MgCl}_{2}$ (see Note 1)

6. $10 \%(\mathrm{v} / \mathrm{v})$ Triton $\mathrm{X}-100$ (see Note 2)

7. $2 \%(v / v)$ Sarkosyl (Sigma-Aldrich, cat. no. L5125) (see Note 2)

8. $2 \%(\mathrm{v} / \mathrm{v})$ Tween-20 (see Note 2 )

9. $10 \%$ Igepal® CA-630 (Millipore Sigma cat. no. I8896) (see Note 2)

10. 0.1 M DTT (see Note 2)

11. $1 \mathrm{M}$ Sucrose (see Note 2)

12. 0.5 M EDTA, pH 8.0 (see Note 2)

13. $0.1 \mathrm{M}$ EGTA, pH 8.0 (see Note 2)

14. Tris-Cl, pH 6.8 (See Note 2)

15. Tris-Cl, pH 7.4 (See Note 2)

16. Tris-Cl, pH 8.0 (See Note 2)

17. Glycerol

18. $1 \mathrm{~N} \mathrm{NaOH}$

19. $100 \%$ Ethanol

20. $75 \%$ Ethanol

21. Biotin-11-CTP $10 \mathrm{mM}$ (PerkinElmer, cat. no. NEL542001EA)

22. Biotin-11-UTP $10 \mathrm{mM}$ (PerkinElmer, cat. no. NEL543001EA)

23. Biotin-11-GTP $10 \mathrm{mM}$ (PerkinElmer, cat. no. NEL545001EA)

24. Biotin-11-ATP $10 \mathrm{mM}$ (PerkinElmer, cat. no. NEL544001EA)

25. GTP, $100 \mathrm{mM}$ (Roche, cat. no. 11277057001)

26. ATP, $100 \mathrm{mM}$ (Roche, cat. no. 11277057001)

27. Trypan Blue

28. Dynabeads ${ }^{\mathrm{TM}}$ MyOne ${ }^{\mathrm{TM}}$ Streptavidin C1 Beads (Invitrogen, cat. no. 65002) 29. TRIzol ${ }^{\mathrm{TM}}$ Reagent (Invitrogen, cat. no. 15596018)

30. TRIzol ${ }^{\mathrm{TM}}$ LS Reagent (Invitrogen, cat. no. 10296028) (optional, see Note 3) 31. Total RNA Purification Kit (Norgen, cat. no. 37500) (optional, see Note 3) 32. Chloroform 
33. GlycoBlue ${ }^{\mathrm{TM}}$ (Invitrogen, cat. no. AM9515)

34. SUPERase-In ${ }^{\mathrm{TM}}$ RNase Inhibitor (20 U/ $\mu \mathrm{L}$ ) (Invitrogen, cat. no. AM2694)

35. Pierce ${ }^{\mathrm{TM}}$ Protease Inhibitor Tablets (Thermo Scientific cat. no. A32963)

36. T4 RNA Ligase (10 U/ $\mu \mathrm{L})$, supplied with 10X T4 RNA ligase buffer, $10 \mathrm{mM}$ ATP and 50\% (w/v) PEG8000 (NEB cat. no. M0204S)

37. RNA 5' pyrophosphohydrolase (RppH; $5 \mathrm{U} / \mu \mathrm{L}$ ) (NEB, cat. no. M0356S)

38. 10X ThermoPol Reaction Buffer (NEB, cat. no. B9004S)

39. T4 polynucleotide kinase (PNK; $10 \mathrm{U} / \mu \mathrm{L}$ ), supplied with 10X PNK buffer (NEB, cat. no. M0201)

40. Maxima H Minus Reverse Transcriptase (200 U/ $\mu \mathrm{L}$ ) (Thermo Scientific, cat. no. EP0751)

41. dNTP mix, 12.5mM each (Roche, cat. no. 03622614001)

42. Q5® High-Fidelity DNA Polymerase, supplied with $5 X$ Q5 Reaction Buffer and 5X High GC-Enhancer (NEB cat. no. M0491S)

43. Micro Bio-Spin ${ }^{\mathrm{TM}}$ RNase free P-30 Gel Columns (Bio-Rad, cat. no. 7326250) (optional, see Note 3 )

44. RNA and DNA oligos (IDT DNA) (see Table 1 and Notes 4-6)

45. Agencourt AMPure XP SPRI beads (Beckman-Coulter, cat. no. A63880)

46. SYBR Gold stain (Invitrogen, cat. no. S11494)

47. Costar ${ }^{\circledR}$ Spin- $X ® 0.22 \mu \mathrm{m}$ Centrifuge Tube Filters (Corning, cat. no. 1860)

48. SsoAdvanced Universal SYBR Green Supermix (BioRad, cat. no. 1725270)

\subsection{Buffers}

1. Permeabilization Buffer: $10 \mathrm{mM}$ Tris- $\mathrm{Cl}[\mathrm{pH} 8.0], 10 \mathrm{mM} \mathrm{KCl}, 250 \mathrm{mM}$ Sucrose, $5 \mathrm{mM} \mathrm{MgCl}$, $1 \mathrm{mM}$ EGTA, 0.1\% (v/v) Igepal, $0.5 \mathrm{mM}$ DTT, 0.05\% (v/v) Tween-20, and 10\% (v/v) Glycerol in DEPC $\mathrm{H}_{2} \mathrm{O}$. Add 1 Pierce protease inhibitor tablet and $10 \mu$ I SUPERase-In RNase inhibitor per $50 \mathrm{~mL}$ (see Note 7)

2. Cell Wash buffer: $10 \mathrm{mM}$ Tris- $\mathrm{Cl}[\mathrm{pH} 8.0], 10 \mathrm{mM} \mathrm{KCl}, 250 \mathrm{mM}$ sucrose, $5 \mathrm{mM} \mathrm{MgCl} 2,1 \mathrm{mM}$ EGTA, $0.5 \mathrm{mM}$ DTT, and 10\% (v/v) Glycerol in DEPC $\mathrm{H}_{2} \mathrm{O}$. Add 1 Pierce protease Inhibitor tablet and $10 \mu$ SUPERase-In RNase inhibitor per $50 \mathrm{~mL}$ (see Note 7)

3. Freeze buffer: $50 \mathrm{mM}$ Tris-Cl [pH 8.0], $40 \%(\mathrm{v} / \mathrm{v})$ glycerol, $5 \mathrm{mM} \mathrm{MgCl}$, $1.1 \mathrm{mM}$ EDTA, and $0.5 \mathrm{mM}$ DTT in DEPC $\mathrm{H}_{2} \mathrm{O}$. Add $10 \mu$ SUPERase-In RNase inhibitor per $50 \mathrm{~mL}$ (see Note 7)

4. Bead Preparation Buffer: $0.1 \mathrm{~N} \mathrm{NaOH}$ and $50 \mathrm{mM} \mathrm{NaCl}$ in DEPC $\mathrm{H}_{2} \mathrm{O}$.

5. Bead Binding Buffer: $10 \mathrm{mM}$ Tris- $\mathrm{HCl}[\mathrm{pH} 7.4], 300 \mathrm{mM} \mathrm{NaCl}, 0.1 \%(\mathrm{v} / \mathrm{v})$ Triton X-100, 1 mM EDTA in DEPC $\mathrm{H}_{2} \mathrm{O}$. Add $2 \mu$ I SUPERase-In RNase 
Inhibitor per $10 \mathrm{~mL}$ (see Note 7)

6. High Salt Wash buffer: $50 \mathrm{mM}$ Tris- $\mathrm{HCl}[\mathrm{pH} 7.4], 2 \mathrm{M} \mathrm{NaCl}, 0.5 \%(\mathrm{v} / \mathrm{v})$ Triton $\mathrm{X}-100$, and $1 \mathrm{mM}$ EDTA in DEPC $\mathrm{H}_{2} \mathrm{O}$. Add $2 \mu \mathrm{l}$ SUPERase-In RNase Inhibitor per $10 \mathrm{~mL}$ (see Note 7)

7. Low Salt Wash Buffer: $5 \mathrm{mM}$ Tris-HCl [pH 7.4], $0.1 \%(\mathrm{v} / \mathrm{v})$ Triton X-100, and $1 \mathrm{mM}$ EDTA in DEPC $\mathrm{H}_{2} \mathrm{O}$. Add $2 \mu$ I SUPERase-In RNase Inhibitor per 10 $\mathrm{mL}$ (see Note 7)

8. 2X Run-On Master Mix (2XROMM): $10 \mathrm{mM}$ Tris-Cl [pH 8.0], $5 \mathrm{mM} \mathrm{MgCl} 2,1$ mM DTT, 300 mM KCl, $40 \mu \mathrm{M}$ Biotin-11-CTP, $40 \mu \mathrm{M}$ Biotin-11-UTP, $40 \mu \mathrm{M}$ Biotin-11-ATP, $40 \mu \mathrm{M}$ Biotin-11-GTP, 1\% (w/v) Sarkosyl in DEPC $\mathrm{H}_{2} \mathrm{O}$. Add 1 $\mu \mathrm{L}$ SUPERase-In RNase Inhibitor per reaction (see Note 8).

\subsection{Consumables}

1. Low-bind, nuclease-free microcentrifuge tubes $(0.5$ and $1.5 \mathrm{~mL})$

2. Low-bind, nuclease-free, filtered pipette tips

3. Wide bore, low-bind, nuclease-free, filtered P1000 and P200 tips (or cut standard bore $\sim 1 \mathrm{~cm}$ from tip) 


\section{Methods}

\subsection{Cell Permeabilization}

! CRITICAL: ALL steps should be carried out on ice or in a cold room

1. Prepare permeabilization buffer, wash buffer, and freeze buffer and place on ice (see Note 7).

2. Proceed using one of the following options:

Option 3.1.2.1: Adherent cells (volumes are for $10 \mathrm{~cm}$ plates):

1. Wash cells with $10 \mathrm{~mL}$ ice cold PBS.

2. Repeat the PBS wash step for a total of two washes.

3. Add $5 \mathrm{~mL}$ ice cold permeabilization buffer, scrape cells, and transfer to a conical tube.

4. Rinse plate with $5 \mathrm{~mL}$ permeabilization buffer and pool cells in conical tube $\left(\mathrm{V}_{\mathrm{f}}=10 \mathrm{~mL}\right)$.

Option 3.1.2.2: Suspension cells:

1. Transfer cells into conical tube and spin down at $700-1000 \times \mathrm{g}$ for 4 min at $4^{\circ} \mathrm{C}$ (see Notes 9-10).

2. Wash with $10 \mathrm{~mL}$ ice cold PBS (see Notes 10-11).

3. Repeat the PBS wash for a total of two washes.

4. Resuspend in $10 \mathrm{~mL}$ cold permeabilization buffer (see Note 11).

3. Continue here from step 3.1.2.1.4 or 3.1.2.2.4.

4. Incubate on ice for $5 \mathrm{~min}$.

5. Check for permeabilization with Trypan blue. Greater than $98 \%$ permeabilization is ideal (see Note 12).

6. Spin down at $700-1000 \times \mathrm{g}$ for $4 \mathrm{~min}$ at $4^{\circ} \mathrm{C}$ (see Notes 9-10).

7. Wash with $10 \mathrm{~mL}$ ice cold cell wash buffer (see Notes 10-11).

8. Repeat the cell wash buffer wash for a total of two washes.

9. Decant wash buffer, and then carefully pipette off remaining buffer and discard without disturbing the cell pellet.

10. Using wide-bore tips, resuspend in $250 \mu \mathrm{L}$ cold freeze buffer and transfer to a $1.5 \mathrm{~mL}$ tube.

11. Rinse the conical tube with an additional $250 \mu \mathrm{L}$ freeze buffer and pool $\left(\mathrm{V}_{\mathrm{f}}=\right.$ $500 \mu \mathrm{L})$.

12. Count cells and add permeabilized spike-in cells if desired (see Notes 1314). 
13. Spin down at $1000 \times \mathrm{g}$ for $5 \mathrm{~min}$ at $4^{\circ} \mathrm{C}$ (see Note 15).

14. Resuspend the desired number of cells for each run-on reaction in $52 \mu \mathrm{L}$ freeze buffer (see Note 16).

15. Continue to the run-on or snap freeze $52 \mu \mathrm{L}$ aliquots in $\mathrm{LN}_{2}$ and store at $80^{\circ} \mathrm{C}$ (see Note 17 ).

\subsection{Preparation}

1. Pre-chill a microcentrifuge to $4^{\circ} \mathrm{C}$.

2. Set a heat block with water in the wells to $37^{\circ} \mathrm{C}$ and another to $65^{\circ} \mathrm{C}$ and allow temperature to equilibrate.

3. Prepare bead preparation buffer, high salt wash buffer, low salt wash buffer, and binding buffer (see Note 7).

4. For each run-on reaction, wash $10 \mu \mathrm{L}$ Dynabeads ${ }^{\mathrm{TM}}$ MyOne $^{\mathrm{TM}}$ Streptavidin $\mathrm{C} 1$ Beads once in $1 \mathrm{~mL}$ bead preparation buffer using a magnet stand. Beads can be washed in bulk (see Notes 18-19).

5. Wash beads twice with $1 \mathrm{~mL}$ binding buffer (see Note 19-20).

6. Resuspend the beads in $25 \mu \mathrm{L}$ binding buffer per sample. Place beads on ice or at $4^{\circ} \mathrm{C}$ until needed.

\subsection{Run-On Reaction}

1. Prepare $2 \mathrm{XROMM}$ equilibrate at $37^{\circ} \mathrm{C}\left(30^{\circ} \mathrm{C}\right.$ for Drosophila) (see Note 8 and 21).

2. Using a wide bore tip, add $50 \mu \mathrm{L}$ of permeabilized cells to new $1.5 \mathrm{~mL}$ tube.

3. Pipette $50 \mu \mathrm{L}$ of preheated $2 \mathrm{XROMM}$ into each reaction tube (already containing permeabilized cells). Gently and thoroughly pipette the mixture 15 times. It is extremely important to thoroughly mix the reaction so that nucleotides diffuse into highly viscous chromatin!

4. Incubate in a thermomixer at $37^{\circ} \mathrm{C}\left(30^{\circ} \mathrm{C}\right.$ for Drosophila) at $750 \mathrm{RPM}$ for 5 min. Have RL buffer from Norgen kit or TRIzol LS ready for use.

5. Proceed to step 3.4.1.1 or 3.4.1.2 depending on choice of RNA extraction method immediately after the $5 \mathrm{~min}$ reaction is complete (take the sample off the heat block and immediately add buffer RL or TRIzol LS). 
Use the table below to coordinate timing of run-on reaction and addition of TRIzol or Buffer RL. Start the timer (counting up) when you add the first sample:

\begin{tabular}{|c|c|}
\hline Time & Step \\
\hline 00:00 & Mix permeabilized cells with 2XROMM for Sample 1 \\
\hline 01:00 & Mix permeabilized cells with 2XROMM for Sample 2 \\
\hline 02:00 & Mix permeabilized cells with 2XROMM for Sample 3 \\
\hline 03:00 & Mix permeabilized cells with 2XROMM for Sample 4 \\
\hline $04: 00$ & Mix permeabilized cells with 2XROMM for Sample 5 \\
\hline 05:00 & Add buffer RL or TRIzol LS to Sample 1, vortex briefly \\
\hline $06: 00$ & Add Buffer RL or TRIzol LS to Sample 2, vortex briefly \\
\hline $07: 00$ & Add Buffer RL or TRIzol LS to Sample 3, vortex briefly \\
\hline $08: 00$ & Add Buffer RL or TRIzol LS to Sample 4, vortex briefly \\
\hline 09:00 & Add Buffer RL or TRIzol LS to Sample 5, vortex briefly \\
\hline
\end{tabular}

383

\subsection{Total RNA Extraction and Base Hydrolysis}

1. Proceed from step 3.3.5 to one of the following options:

Option 3.4.1.1: NORGEN RNA Extraction (see Note 3):

1. Add $350 \mu \mathrm{L} R L$ buffer and vortex.

2. Add $240 \mu \mathrm{L} 100 \%$ ethanol and vortex.

3. Apply solution to Norgen RNA extraction column.

4. Spin at $3,500 \times \mathrm{g}$ for $1 \mathrm{~min}$ at $25^{\circ} \mathrm{C}$.

5. Add $400 \mu \mathrm{L}$ wash solution A (ensure ethanol has been added).

6. Spin at $14,000 \times \mathrm{g}$ for $1 \mathrm{~min}$ at $25^{\circ} \mathrm{C}$.

7. Discard flow through.

8. Repeat wash (steps 6 \& 7) for a total of two washes.

9. Spin at $14,000 \times \mathrm{g}$ for 2 min to dry column.

10. Add $50 \mu \mathrm{L} \mathrm{DEPC} \mathrm{H}_{2} \mathrm{O}$ and vortex.

11. Elute by spinning at $200 \times \mathrm{g}$ for $2 \mathrm{~min}$ at $25^{\circ} \mathrm{C}$ and then at $14,000 \times \mathrm{g}$ for $1 \mathrm{~min}$ at $25^{\circ} \mathrm{C}$.

12. Elute again with $50 \mu \mathrm{L} \mathrm{H}_{2} \mathrm{O}$ and pool eluates $\left(\mathrm{V}_{\mathrm{f}}=100 \mu \mathrm{L}\right)$.

13. Denature at $65^{\circ} \mathrm{C}$ for $30 \mathrm{sec}$ and then snap cool on ice.

14. Add $25 \mu \mathrm{L}$ ice cold $1 \mathrm{~N} \mathrm{NaOH}$ and incubate 10 min on ice.

15. Add $125 \mu \mathrm{L}$ cold $1 \mathrm{M}$ Tris- $\mathrm{Cl} \mathrm{pH} 6.8$, mix by pipetting.

16. Add $5 \mu \mathrm{L} 5 \mathrm{M} \mathrm{NaCl}$ and $1 \mu \mathrm{L}$ GlycoBlue and mix.

17. Add $625 \mu \mathrm{L} 100 \%$ Ethanol and vortex (see Note 22).

18. Centrifuge the samples at $>20,000 \times \mathrm{g}$ for 20 minutes at $4^{\circ} \mathrm{C}$ (see 
Note 23).

19. Carefully pipette supernatant off and discard (see Note 24).

20. Add $750 \mu \mathrm{L} 70 \%$ ethanol.

21. Mix by gentle inversion and spin down briefly.

22. Carefully pipette supernatant off and discard (see Note 24).

23. Airdry the RNA pellet (see Note 25).

24. Resuspend in $6 \mu \mathrm{L} \mathrm{DEPC} \mathrm{H}_{2} \mathrm{O}$.

\section{Option 3.4.1.2: Trizol LS RNA Extraction (See Note 3):}

1. Add $250 \mu \mathrm{L}$ TRIzol LS with a wide bore P1000 tip, pipette vigorously but carefully $>10 X$ until all white globs of nucleoproteins are homogenized.

2. Pipette mix again with a standard bore P1000 tip. Samples should be completely homogenous.

3. Vortex vigorously for at least 15 seconds.

4. Incubate samples on ice until all run-on reactions are complete.

5. Add $65 \mu \mathrm{L}$ chloroform (see Note 26 ).

6. Vortex the samples at max speed for $15 \mathrm{sec}$, then incubate on ice for 3 min.

7. Centrifuge the samples at $>20,000 \times \mathrm{g}$ for $8 \mathrm{~min}$ at $4^{\circ} \mathrm{C}$.

8. Transfer the $\sim 200 \mu \mathrm{L}$ aqueous phase into a new tube (see Note 27).

9. Add $1 \mu \mathrm{L}$ of GlycoBlue and mix.

10. Add 2.5X volumes $(\sim 500 \mu \mathrm{L}) 100 \%$ ethanol and vortex.

11. Centrifuge at $>20,000 \times \mathrm{g}$ for $20 \mathrm{~min}$ at $4^{\circ} \mathrm{C}$ (see Note 23).

12. Carefully pipette supernatant off and discard (see Note 24).

13. Add $750 \mu \mathrm{L} 70 \%$ ethanol.

14. Mix by gentle inversion and quickly spin down.

15. Carefully pipette supernatant off and discard (see Note 24).

16. Airdry the RNA pellet (see Note 25).

17. Resuspend in $30 \mu \mathrm{L} \mathrm{DEPC} \mathrm{H}_{2} \mathrm{O}$.

18. Briefly denature at $65^{\circ} \mathrm{C}$ for $30 \mathrm{sec}$ and then snap cool on ice.

19. Add $7.5 \mu \mathrm{L}$ ice cold $1 \mathrm{~N} \mathrm{NaOH}$ and incubate on ice for $10 \mathrm{~min}$.

20. Add $37.5 \mu \mathrm{L} 1 \mathrm{M}$ TrisCl pH 6.8, mix by pipetting.

21. Pass through a calibrated Bio-Rad RNase free P-30 column (follow manufacturer's instructions).

22. Bring volume to $200 \mu \mathrm{L}$ with DEPC $\mathrm{H}_{2} \mathrm{O}$ (add $\sim 125 \mu \mathrm{L}$ ).

23. Add $1 \mu \mathrm{L}$ Glycoblue and $8 \mu \mathrm{L} 5 \mathrm{M} \mathrm{NaCl}$ and vortex.

24. Add $500 \mu \mathrm{L} 100 \%$ ethanol and vortex (see Note 22). 
25. Centrifuge at $>20,000 \times \mathrm{g}$ for 20 minutes at $4^{\circ} \mathrm{C}$ (see Note 23).

26. Carefully pipette supernatant off and discard (see Note 24).

27. Add $750 \mu \mathrm{L} 70 \%$ ethanol.

28. Mix by gentle inversion and quickly spin down.

29. Carefully pipette supernatant off and discard (see Note 24).

30. Airdry the RNA pellet (see Note 25).

31. Resuspend in $6 \mu \mathrm{L} \mathrm{DEPC} \mathrm{H}_{2} \mathrm{O}$.

\subsection{3' RNA Adaptor Ligation}

1. Continue here from step 3.4.1.1.24 or 3.4.1.2.31:

2. Add $1 \mu \mathrm{L} 10 \mu \mathrm{M}$ VRA3 (see Note 28).

3. Denature at $65^{\circ} \mathrm{C}$ for $30 \mathrm{sec}$ and snap cool on ice.

4. Prepare ligation mix in the following order (see Note 29):

\begin{tabular}{|c|c|}
\hline Reagent & Volume \\
\hline 10X T4 RNA ligase buffer & $2 \mu \mathrm{L}$ \\
\hline ATP (10 mM) & $2 \mu \mathrm{L}$ \\
\hline SUPERase-In RNase Inhibitor & $1 \mu \mathrm{L}$ (see Note 30) \\
\hline $50 \%$ PEG8000 & $6 \mu \mathrm{L}$ \\
\hline T4 RNA Ligase I (NEB) & $2 \mu \mathrm{L}$ \\
\hline
\end{tabular}

5. Add $13 \mu \mathrm{L}$ and mix by pipetting $10-15 X\left(V_{f}=20 \mu \mathrm{L}\right)$.

6. Incubate at $25^{\circ} \mathrm{C}$ for $1 \mathrm{~h}$.

\subsection{Streptavidin Bead Binding}

1. Add $55 \mu \mathrm{L}$ binding buffer to each sample $\left(V_{f}=75 \mu \mathrm{L}\right)$.

2. Add $25 \mu \mathrm{L}$ pre-washed beads to each sample $\left(\mathrm{V}_{\mathrm{f}}=100 \mu \mathrm{L}\right)$.

3. Incubate for $20 \mathrm{~min}$ at $25^{\circ} \mathrm{C}$ with end to end rotation.

4. Wash once with $500 \mu \mathrm{L}$ High Salt Wash buffer with tube swap (see Notes 19, 31-32).

5. Wash once with $500 \mu \mathrm{L}$ Low Salt Wash buffer (see Notes 19, 31, 33). 


\subsection{On-Bead 5' Hydroxyl Repair}

1. Resuspend beads in $19 \mu \mathrm{L}$ PNK mix $\left(V_{f}=20 \mu \mathrm{L}\right.$; see Note 34$)$ :

\begin{tabular}{|c|c|}
\hline Reagent & Volume \\
\hline DEPC $\mathrm{H}_{2} \mathrm{O}$ & $13 \mu \mathrm{L}$ \\
\hline 10X PNK buffer & $2 \mu \mathrm{L}$ \\
\hline $10 \mathrm{mM} \mathrm{ATP}$ & $2 \mu \mathrm{L}$ \\
\hline T4 PNK (NEB) & $1 \mu \mathrm{L}$ \\
\hline SUPERase-IN RNase Inhibitor & $1 \mu \mathrm{L}$ (see Note 30) \\
\hline
\end{tabular}

2. Incubate at $37^{\circ} \mathrm{C}$ for $30 \mathrm{~min}$ (see note 35 ).

\subsection{On-Bead 5' Decapping}

1. Place the tubes on a magnet stand and remove supernatant (see Notes 1920,33).

2. Resuspend the beads in $19 \mu \mathrm{L} \mathrm{RppH} \operatorname{mix}\left(\mathrm{V}_{\mathrm{f}}=20 \mu \mathrm{L}\right.$; see Notes 34, 36):

\begin{tabular}{|c|c|}
\hline Reagent & Volume \\
\hline DEPC $\mathrm{H}_{2} \mathrm{O}$ & $15 \mu \mathrm{L}$ \\
\hline 10X ThermoPol Buffer & $2 \mu \mathrm{L}$ \\
\hline RppH & $1 \mu \mathrm{L}$ \\
\hline SUPERase-In RNase Inhibitor & $1 \mu \mathrm{L}$ \\
\hline
\end{tabular}

3. Incubate at $37^{\circ} \mathrm{C}$ for $1 \mathrm{~h}$ (see note 35$)$.

\subsection{On-Bead 5' RNA Adaptor Ligation}

1. Place the tubes on a magnet stand and remove supernatant (see Notes 1920,33).

2. Resuspend the beads in $7 \mu \mathrm{L}$ adapter mix $\left(\mathrm{V}_{\mathrm{f}}=8 \mu \mathrm{L}\right)$ :

\begin{tabular}{|c|c|}
\hline Reagent & Volume \\
\hline $\mathrm{DEPC} \mathrm{H}_{2} \mathrm{O}$ & $6 \mu \mathrm{L}$ \\
\hline REV5 $(10 \mu \mathrm{M})($ see Note 28$)$ & $1 \mu \mathrm{L}$ \\
\hline
\end{tabular}

3. Denature at $65^{\circ} \mathrm{C}$ for $30 \mathrm{sec}$, then snap cool on ice.

4. Prepare ligation mix in the following order (see Note 29): 


\begin{tabular}{|c|c|}
\hline Reagent & Volume \\
\hline 10x T4 RNA ligase buffer & $2 \mu \mathrm{L}$ \\
\hline ATP (10 mM) & $2 \mu \mathrm{L}$ \\
\hline SUPERase-In RNase Inhibitor & $1 \mu \mathrm{L}$ (see Note 30) \\
\hline 50\% PEG8000 & $6 \mu \mathrm{L}$ \\
\hline T4 RNA ligase I & $1 \mu \mathrm{L}$ \\
\hline
\end{tabular}

5. Add $12 \mu \mathrm{L}$ to each tube $\left(\mathrm{V}_{\mathrm{f}}=20 \mu \mathrm{L}\right)$.

6. Incubate at $25^{\circ} \mathrm{C}$ for $1 \mathrm{~h}$ (see Note 35 ).

\subsection{TRIzol Elution of RNA}

1. Wash once with $500 \mu \mathrm{L}$ High Salt Wash buffer with tube swap (see Notes 19, 31-32).

2. Wash once with $500 \mu \mathrm{L}$ Low Salt Wash buffer (see Notes 19, 31, 33).

3. Resuspend beads in $300 \mu \mathrm{L}$ TRIzol.

4. Vortex at max speed for $>20 \mathrm{sec}$, then incubate on ice for $3 \mathrm{~min}$.

5. Add $60 \mu \mathrm{L}$ chloroform (see Note 26).

6. Vortex at max speed for $15 \mathrm{sec}$, then incubate on ice for $3 \mathrm{~min}$.

7. Centrifuge at $>20,000 \times \mathrm{g}$ for $8 \mathrm{~min}$ at $4^{\circ} \mathrm{C}$.

8. Transfer the aqueous phase $(\sim 180 \mu \mathrm{L})$ to a new tube (see Note 27$)$.

9. Add $1 \mu \mathrm{L}$ GlycoBlue and mix.

10. Add $2.5 \mathrm{X}$ volumes $(\sim 450 \mu \mathrm{L}) 100 \%$ ethanol and vortex.

11. Centrifuge the samples at $>20,000 \times \mathrm{g}$ for $20 \mathrm{~min}$ at $4^{\circ} \mathrm{C}$ (see Note 23).

12. Carefully pipette supernatant off and discard (see Note 24).

13. Add $750 \mu \mathrm{L} 70 \%$ ethanol.

14. Mix by gentle inversion and quickly spin down.

15. Carefully pipette supernatant off and discard (see Note 24).

16. Airdry the RNA pellet (see Note 25).

\subsection{Off-Bead Reverse Transcription}

1. Resuspend RNA pellet in $13.5 \mu \mathrm{L} R T$ resuspension mix (see Note 37):

\begin{tabular}{|c|c|}
\hline Reagent & Volume \\
\hline $\mathrm{DEPC} \mathrm{H}_{2} \mathrm{O}$ & $8.7 \mu \mathrm{L}$ \\
\hline $\mathrm{RP} 1(10 \mu \mathrm{M})$ & 4 \\
\hline dNTP $\operatorname{mix}(12.5 \mathrm{mM}$ each $)$ & $0.8 \mu \mathrm{L}$ \\
\hline
\end{tabular}

2. Denature at $65^{\circ} \mathrm{C}$ for $5 \mathrm{~min}$ and snap cool on ice. 
3. Prepare RT master mix:

\begin{tabular}{|c|c|}
\hline Reagent & Volume \\
\hline 5X RT Buffer & $4 \mu \mathrm{L}$ \\
\hline 100 mM DTT & $1 \mu \mathrm{L}$ \\
\hline SUPERase-In RNase Inhibitor & $0.5 \mu \mathrm{L}$ (see Note 30) \\
\hline Maxima H Minus RT enzyme & $1 \mu \mathrm{L}$ \\
\hline
\end{tabular}

4. Add $6.5 \mu \mathrm{L}$ to each sample $\left(\mathrm{V}_{\mathrm{f}}=20 \mu \mathrm{L}\right)$.

5. Cycle as follows: $50^{\circ} \mathrm{C}$ for $30 \mathrm{~min}, 65^{\circ} \mathrm{C}$ for $15 \mathrm{~min}, 85^{\circ} \mathrm{C}$ for $5 \mathrm{~min}$, then hold at $4^{\circ} \mathrm{C}$.

6. Immediately proceed to PreCR, test amplification, or full-scale amplification. Samples can be stored overnight at $-20^{\circ} \mathrm{C}$ (see Notes $38-39$ ).

\subsection{PreCR (Optional, see Note 38)}

1. Add $2.5 \mu \mathrm{L} \mathrm{RPI-n}$ indexed primer $(10 \mu \mathrm{M})$ to each sample. Use different barcodes for samples that will be pooled and sequenced together.

2. Prepare the PreCR master mix:

\begin{tabular}{|c|c|}
\hline Reagent & Volume \\
\hline ddH $_{2} \mathrm{O}$ & $33.5 \mu \mathrm{L}$ \\
\hline 5x Q5 buffer & $20 \mu \mathrm{L}$ \\
\hline 5x Q5 enhancer & $20 \mu \mathrm{L}$ \\
\hline Primer RP1 (10 $\mu \mathrm{M})$ & $1 \mu \mathrm{L}$ \\
\hline dNTP mix (12.5 mM each) & $2 \mu \mathrm{L}$ \\
\hline Q5 polymerase (NEB) & $1 \mu \mathrm{L}$ \\
\hline
\end{tabular}

3. Add $77.5 \mu \mathrm{L}$ of the PreCR mix to each sample for final volume $100 \mu \mathrm{L}$ (see Note 40).

4. Amplify libraries for 5 cycles on thermal cycler using the following settings: 
5. Store samples at $-20^{\circ} \mathrm{C}$ or proceed to test amplification.

\subsection{Test Amplification (Gel) (Optional, see Note 39)}

1. Make the first dilution:

a. If PreCR was performed, add $7.7 \mu \mathrm{L}$ of the $100 \mu \mathrm{L}$ PreCR reaction to $0.3 \mu \mathrm{L} \mathrm{ddH} \mathrm{H}_{2} \mathrm{O}$ for a final volume of $8 \mu \mathrm{L}$ (see Note 41 ).

b. If PreCR was skipped, add $1.54 \mu \mathrm{L}$ of the $20 \mu \mathrm{L} R \mathrm{R}$ reaction to 6.46 $\mu \mathrm{L} \mathrm{ddH} \mathrm{H}_{2} \mathrm{O}$ for a final volume of $8 \mu \mathrm{L}$ (see Note 41 ).

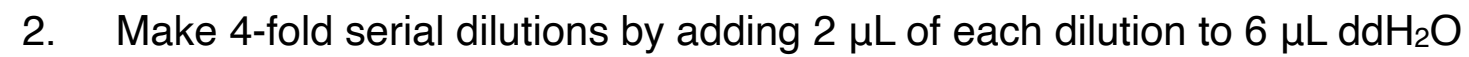
for the next dilution.

3. Remove and discard $2 \mu \mathrm{L}$ from the final dilution (all dilutions should now be $6 \mu \mathrm{L})$.

4. Choose a target number of total cycles for test amplification using the table below (see Note 42). The first dilution simulates full-scale amplification at the total number of cycles (PreCR cycles + Test Amp cycles) minus 4. Subtract 2 cycles sequentially for the following dilutions.

\begin{tabular}{|c|c|c|c|c|c|c|c|c|}
\hline Dilution & $\mathbf{1}$ & $\mathbf{2}$ & $\mathbf{3}$ & $\mathbf{4}$ & $\mathbf{5}$ & $\mathbf{6}$ & $\mathbf{7}$ & $\mathbf{8}$ \\
\hline 19 Total Cycles & 15 & 13 & 11 & 9 & 7 & 5 & 3 & 1 \\
\hline 21 Total Cycles & 17 & 15 & 13 & 11 & 9 & 7 & 5 & 3 \\
\hline 23 Total Cycles & 19 & 17 & 15 & 13 & 11 & 9 & 7 & 5 \\
\hline
\end{tabular}

5. Make test PCR mix:

\begin{tabular}{|l|l|}
\hline Reagent & Volume \\
\hline $\mathrm{H}_{2} \mathrm{O}$ & $4.4 \mu \mathrm{L}$ \\
\hline 5x Q5 buffer & $4 \mu \mathrm{L}$ \\
\hline 5x Q5 enhancer & $4 \mu \mathrm{L}$ \\
\hline Primer RP1 $(10 \mu \mathrm{M})$ & $0.5 \mu \mathrm{L}$ \\
\hline Primer RPI-n $(10 \mu \mathrm{M})$ & $0.5 \mu \mathrm{L}$ \\
\hline dNTP mix $(12.5 \mathrm{mM}$ each) & $0.4 \mu \mathrm{L}$ \\
\hline Q5 polymerase (NEB) & $0.2 \mu \mathrm{L}$ \\
\hline
\end{tabular}

6. Add $14 \mu \mathrm{L}$ PCR mix to the $6 \mu \mathrm{L}$ diluted test samples $\left(\mathrm{V}_{\mathrm{f}}=20 \mu \mathrm{L}\right)$.

7. Amplify reactions for the desired amount of cycles using following settings: total target test amplification cycles.
a. $\quad 95^{\circ} \mathrm{C}$ for $2 \min$ 
b. $95^{\circ} \mathrm{C}$ for $30 \mathrm{sec}$

c. $\quad 65^{\circ} \mathrm{C}$ for $30 \mathrm{sec}$ (see Note 43 )

d. $72^{\circ} \mathrm{C}$ for $30 \mathrm{sec}$

e. Go to step 2 for the desired number of cycles

f. $\quad 72^{\circ} \mathrm{C}$ for $5 \mathrm{~min}$

g. Hold at $4^{\circ} \mathrm{C}$

8. Mix with gel loading dye to $1 \mathrm{X}$ and run $10 \mu \mathrm{L}$ on a $2.2 \%$ Agarose gel or run 2 $\mu \mathrm{L}$ on a native $8 \%$ polyacrylamide gel and stain with SYBR Gold.

9. Use the test amplification gel to determine the appropriate number of cycles for full-scale amplification (see Note 44).

\subsection{Test Amplification (qPCR) (Optional, see Note 39)}

1. Add $1.54 \mu \mathrm{L}$ of the $20 \mu \mathrm{L} R T$ reaction to $0.46 \mu \mathrm{L} \mathrm{ddH_{2 }} \mathrm{O}\left(\mathrm{V}_{\mathrm{f}}=2 \mu \mathrm{L}\right)$.

2. Make the qPCR master mix:

\begin{tabular}{|c|c|}
\hline Reagent & Volume \\
\hline Primer RP1 $(10 \mu \mathrm{M})$ & $0.25 \mu \mathrm{L}$ \\
\hline Primer RPI-n $(10 \mu \mathrm{M})$ & $0.25 \mu \mathrm{L}$ \\
\hline 2X SsoAdvanced Universal SYBR Green Supermix & $5 \mu \mathrm{L}$ \\
\hline $\mathrm{H}_{2} \mathrm{O}$ & $2.5 \mu \mathrm{L}$ \\
\hline
\end{tabular}

3. Add $8 \mu \mathrm{L}$ of the $\mathrm{qPCR}$ master mix to $2 \mu \mathrm{L}$ diluted RT reaction $\left(\mathrm{V}_{\mathrm{f}}=10 \mu \mathrm{L}\right)$.

4. Quickly spin plate to collect liquid.

5. Amplify in a real-time PCR system using the following conditions:

a. Amplification

i. $\quad 98^{\circ} \mathrm{C}$ for $2 \mathrm{~min}$

ii. $\quad 98^{\circ} \mathrm{C}$ for $15 \mathrm{sec}$

iii. $\quad 60^{\circ} \mathrm{C}$ for $60 \mathrm{sec}$

iv. Go to step 2 for 39 additional cycles

b. Melting Curve

i. $\quad 95^{\circ} \mathrm{C}$ for $15 \mathrm{sec}$

ii. $\quad 60^{\circ} \mathrm{C}$ for $1 \mathrm{~min}$

iii. $\quad 96{ }^{\circ} \mathrm{C}$ for $15 \mathrm{sec}$

iv. $\quad 60^{\circ} \mathrm{C}$ for $16 \mathrm{sec}$

6. Calculate the number of full-scale amplification cycles as the cycle number where $\mathrm{Rn}$ reaches $0.25 \times \mathrm{Rn}_{\max }$. 


\subsection{Full-Scale Amplification}

607

608

609

610

611

612

613

614

615

616

617

618

619

620

621

622

623

624

625

626

1. If PreCR and Test Amplification were skipped:

a. Add $2.5 \mu \mathrm{L}$ of an RPI-n indexed primer $(10 \mu \mathrm{M})$ to each $20 \mu \mathrm{L} \mathrm{RT}$ reaction. Use different barcodes for samples that will be pooled and sequenced on a single lane.

b. Prepare the PCR master mix in step 2 of section 3.12 (PreCR).

c. Add $77.5 \mu \mathrm{L}$ PCR master mix to each sample for final volume $100 \mu \mathrm{L}$ (see Note 40).

d. Run the desired number of cycles (see below)

2. If PreCR was skipped but Test Amplification was performed:

a. Add $2.5 \mu \mathrm{L}$ of an RPI-n indexed primer $(10 \mu \mathrm{M})$ to the remaining $18.5 \mu \mathrm{L} \mathrm{RT}$ reaction. Use different barcodes for samples that will be pooled and sequenced on a single lane.

b. Prepare the PCR master mix in step 2 of section 3.12 (PreCR) but

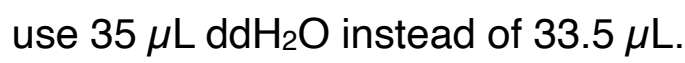

c. Add $79 \mu \mathrm{L}$ PCR master mix to each sample for final volume $100 \mu \mathrm{L}$ (see Note 40).

d. Run the desired number of cycles (see below).

3. If PreCR and Test Amplification were performed:

a. Prepare the following spike-in PCR mix: 
627

\begin{tabular}{|c|c|}
\hline Reagent & Volume \\
\hline ddH $_{2} \mathrm{O}$ & $3.7 \mu \mathrm{L}$ \\
\hline 5x Q5 buffer & $1.5 \mu \mathrm{L}$ \\
\hline 5x Q5 enhancer & $1.5 \mu \mathrm{L}$ \\
\hline dNTP mix (12.5mM each) & $0.5 \mu \mathrm{L}$ \\
\hline Q5 polymerase (NEB) & $0.5 \mu \mathrm{L}$ \\
\hline
\end{tabular}

b. Add 7.7 $\mu \mathrm{L}$ PCR spike-in mix to each sample for final volume $100 \mu \mathrm{L}$ (see Note 40).

c. Run the desired number of cycles.

4. Amplify for the desired number of cycles:

! CRITICAL: Remember to account for PreCR. Subtract 5 cycles from your total target full-scale amplification cycles.

a. $95^{\circ} \mathrm{C}$ for $2 \min$

b. $95^{\circ} \mathrm{C}$ for $30 \mathrm{sec}$

c. $\quad 65^{\circ} \mathrm{C}$ for $30 \mathrm{sec}$ (see Note 43 )

d. $72^{\circ} \mathrm{C}$ for $30 \mathrm{sec}$

e. Go to step 2 for the desired number of cycles

f. $72^{\circ} \mathrm{C}$ for $5 \mathrm{~min}$

g. Hold at $4^{\circ} \mathrm{C}$

5. Allow PCR reactions to reach room temperature.

6. Add $180 \mu \mathrm{L} \mathrm{SPRI} \mathrm{beads} \mathrm{(see} \mathrm{Note} \mathrm{45)} \mathrm{at} \mathrm{room} \mathrm{temperature} \mathrm{and}$ immediately mix by pipetting $>15 \mathrm{X}$.

7. Incubate at room temperature for $5 \mathrm{~min}$.

8. Place on a magnet stand and remove the supernatant.

9. Wash the beads twice with $70 \%$ Ethanol without resuspending.

! CRITICAL: Do not disturb the beads or library recovery will be greatly reduced.

10. Airdry the beads for $5 \mathrm{~min}$. Do not over dry the beads.

11. Resuspend beads in $22 \mu \mathrm{L} 10 \mathrm{mM}$ Tris-Cl, pH 8.0 (no EDTA).

12. Incubate at room temperature for $5 \mathrm{~min}$.

13. Place the beads on a magnet stand and transfer $20 \mu \mathrm{L}$ to a new tube.

14. Quantify the library using the Qubit dsDNA-HS assay and run on a Bioanalyzer.

\subsection{PAGE purification (optional, see Note 46)}

1. Add Orange $\mathrm{G}$ loading dye to $1 \mathrm{X}$ to the entire library volume. 
658

659

660

661

662

663

664

665

666

667

668

669

670

671

672

673

674

675

676

677

678

679

680

681

682

683

684

685

686

687

688

689

690

691

2. Run the samples on a native $8 \%$ polyacrylamide gel.

3. Stain with SYBR Gold.

4. Cut a gel slice from immediately above the adapter dimer to $\sim 650 \mathrm{bp}$ (see Note 44).

5. Place the gel slice in a $0.5 \mathrm{~mL}$ microfuge tube.

6. Make a hole in the bottom of the tube with an $18 \mathrm{G}$ needle.

7. Nest the $0.5 \mathrm{~mL}$ tube in a $1.5 \mathrm{~mL}$ tube and spin at $5000 \mathrm{xg}$ for $1 \mathrm{~min}$.

8. If gel remains in the $0.5 \mathrm{~mL}$ tube, repeat step 7 and pool shredded gel fractions by suspending each in $250 \mu \mathrm{L}$ soaking buffer using a wide-bore P1000 tip.

9. Soak the gel pieces in $0.5 \mathrm{~mL}$ soaking buffer $(\mathrm{TE}+150 \mathrm{mM} \mathrm{NaCl}+0.1 \%$ Tween-20) overnight with agitation at $37^{\circ} \mathrm{C}$.

10. Spin the tube at $5000 \times \mathrm{g}$ for $1 \mathrm{~min}$.

11. Pipette as much of the soaking buffer as possible without transferring gel pieces into a new tube.

12. Add an additional $0.5 \mathrm{~mL}$ soaking buffer and incubate $4 \mathrm{~h}$ at $37^{\circ} \mathrm{C}$ with agitation.

13. Spin the tube at $5000 \times \mathrm{g}$ for $1 \mathrm{~min}$.

14. Pipette as much of the soaking buffer as possible without transferring gel pieces into the tube with the previous eluate.

15. Pass the remaining gel solution through a Costar Spin- $X$ column using a cut P1000 tip and pool with the previous eluate $\left(V_{f}=1 \mathrm{~mL}\right)$

16. Reduce the volume by half $\left(\mathrm{V}_{\mathrm{f}}=0.5 \mathrm{~mL}\right)$ using vacuum dryer at $37^{\circ} \mathrm{C}$.

17. Add 1uL GlycoBlue.

18. Add 2.5X volume $(1.25 \mathrm{~mL}) 100 \%$ ethanol and vortex.

19. Centrifuge at $>20,000 \times \mathrm{g}$ for 20 minutes at $4^{\circ} \mathrm{C}$ (see Note 23).

20. Carefully pipette off the supernatant and discard (see Note 24).

21. Add $750 \mu \mathrm{L}$ of $75 \%$ ethanol.

22. Mix by gentle inversion and quickly spin down.

23. Carefully pipette off the supernatant and discard (see Note 24).

24. Air-dry the RNA pellet (see Note 25).

25. Resuspend the pellet in the desired volume of $10 \mathrm{mM}$ Tris- $\mathrm{Cl}, \mathrm{pH} 8.0$ (no EDTA!). 


\section{Notes}

1. All salt solutions should be prepared in $\mathrm{ddH}_{2} \mathrm{O}$. Then add $0.1 \%(\mathrm{v} / \mathrm{v}) \mathrm{DEPC}$, stir overnight, and autoclave. Tris buffers instead need to be carefully prepared with DEPC-treated dd $\mathrm{H}_{2} \mathrm{O}$.

2. All other solutions (detergents, DTT, sucrose, EDTA/EGTA, and Tris buffers) should be prepared in DEPC dd $\mathrm{H}_{2} \mathrm{O}$ in RNase free containers and filter sterilized. Glassware can be made RNase by filling with water, adding $0.1 \%(\mathrm{v} / \mathrm{v}) \mathrm{DEPC}$, incubating with agitation overnight, and autoclaving. Alternatively, glassware can be baked at $300{ }^{\circ} \mathrm{C}$ for 4 hours.

3. TRIzol LS or the Norgen Total RNA Purification Kit can be used to extract total RNA from the run-on reaction. Both options produce identical results. The Norgen kit is faster and less technically challenging to use, but more expensive. If TRIzol LS is used, Micro Bio-Spin ${ }^{\mathrm{TM}}$ RNase free P-30 Gel Columns are also needed to remove unincorporated biotin-NTPs as the biotin concentration will otherwise overwhelm the binding capacity of the streptavidin beads.

4. REV3 and REV5 sequences are reverse complements of the standard RA3/RA5 adapter design used in the Illumina TruSeq small RNA library prep kit with added 6XN UMIs and a final ligation-optimal fixed base. The oligos are blocked from additional ligation by an inverted $\mathrm{dT} / \mathrm{ddT}$ group. This design results in sequencing of the 3' end of the nascent RNA at the beginning of read 1 using standard Illumina sequencing primers. Standard RA3/RA5 adapters (custom synthesized or from compatible library prep kits) can be substituted, but in this case paired end sequencing is necessary as the 3 ' end of the nascent RNA will be sequenced at the beginning of read 2 .

5. Index sequences in RPI-n primers are standard 6 nt Illumina TruSeq indices. If multiplexing of more than 12 libraries is desired, additional indexed primers can be designed using additional TruSeq $6 \mathrm{nt}$ index sequences. The index sequences must be inserted in the primer reverse complemented because the RPI-n primers are the reverse primers in the library PCR reaction.

6. If desired, specialized REV3 oligos can be designed to facilitate additional in-line barcoding to allow for the pooling of multiple samples after the 3' ligation, which simplifies downstream handling. We have had success with replacing the UMI sequence ( $r$ NrNrNrNNN) with known barcode sequences followed by the final fixed $\mathrm{rU}$. These barcodes are then the first 6 sequenced nucleotides of Read 1 and can be used to computationally demultiplex samples.

7. The permeabilization buffer, cell wash buffer, freeze buffer, and bead washing/binding buffers can be made and filter-sterilized in advance without the DTT, SUPERase-In ${ }^{\mathrm{TM}}$ RNase Inhibitor, and Pierce ${ }^{\mathrm{TM}}$ protease inhibitor tablets. 
DTT, SUPERase-In ${ }^{\text {TM }}$ RNase Inhibitor, and protease inhibitor tablets can be added when buffers are needed. Store buffers at $4^{\circ} \mathrm{C}$. Use DEPC treated glassware or RNase free plasticware.

8. The run-on reaction uses 4 biotin-NTPs. However, ATP and GTP can be substituted at equal concentration for Biotin-11-ATP and Biotin-11-GTP to reduce cost. Biotin-11-ATP and biotin-11-GTP are 10X as expensive as biotin-11-CTP and biotin-11-UTP. With two biotin-NTPs blocking elongation, each polymerase can be expected to extend $\sim 5 \mathrm{nt}$ or less which we find gives sufficient resolution for the vast majority of applications. For low cell number experiments, increase the concentration of the biotin-NTPs to $500 \mu \mathrm{M}$. Biotin-NTP incorporation efficiency is $\sim 60 \%$ with the concentration in the $2 \mathrm{XROMM}$ as written, which is sufficient for experiments using $10^{6}$ cells or greater, but increasing the concentration improves incorporation to $\sim 77 \%$ (data not shown).

9. Use a centrifuge with a swinging bucket rotor for all centrifuge steps during cell permeabilization. Using a fixed angle rotor will shear cells, releasing a smear of white chromatin.

10. Centrifuge speed is cell size dependent. We typically centrifuge HeLa at $800 \times \mathrm{g}$ and Drosophila at $1,000 \times \mathrm{g}$.

11. When resuspending cells during permeabilization after centrifugation steps, first gently resuspend the cell pellet with $1 \mathrm{~mL}$ solution with a wide-bore P1000 tip. Then add the remaining volume (usually $9 \mathrm{~mL}$ ) and mix by gentle inversion.

12. If your cell type is not permeabilized under these conditions, add Triton $\mathrm{X}-100$ to $0.1-0.2 \%$.

13. When processing multiple samples, if counting will cause the cells to sit on ice for greater than $10 \mathrm{~min}$, reserve $10 \mu \mathrm{L}$ for counting, aliquot cells in $100 \mu \mathrm{L}$ aliquots, and snap freeze. Count the cells and then adjust the concentration with freeze buffer after thawing and prior to the run-on.

14. In order to robustly normalize between conditions where a dramatic change in global transcription levels are expected, we add a fixed number of cells of a different species to a fixed number of experimental cells at the permeabilization step. Reads can be mapped to a combined genome, and the number of spike-in mapped reads can then be used as a scaling factor. These cells should be permeabilized prior to the experiment, aliquoted, and added to $1-2 \%$ by cell number after permeabilization and counting, either just prior to freezing or just prior to the run-on reaction. We frequently use Drosophila $S 2$ cells to normalize human cell experiments and vice versa. 
15. Eppendorf tubes can be spun in a fixed angle rotor, but we continue to use a swinging bucket rotor so that cells collect at bottom of tube (this tends to decrease cell loss).

16. We have had success performing this protocol with as few as 50k primary human cells. In general, we find that the quality of libraries will increase until $\sim 1 \times 10^{6}$ cells per run-on but using more cells than this offers little benefit. This will also depend on how transcriptionally active a given cell type is and genome size.

17. Permeabilized cells are stable indefinitely at $-80^{\circ} \mathrm{C}$ (Chu et al., 2018).

18. C1 Streptavidin beads are preferred compared to M280 beads because they have higher binding capacity and use a negatively charged matrix. This significantly reduces carryover of non-biotinylated RNAs including adapter dimers.

19. Be careful not to disturb beads when removing buffers from tubes. Open tube caps prior to placing them on the magnet stand, as opening on the magnet stand can disturb the liquid. Check pipette tip against a white background before discarding liquid to ensure beads are not present.

20. Always quickly spin samples down using a picofuge to remove liquid from tube caps.

21. When preparing the $2 X R O M M$, first add all components other than Sarkosyl and mix by vortexing on high for $>10 \mathrm{sec}$. Collect the solution with a quick spin, add Sarkosyl, and mix thoroughly by pipetting carefully to avoid bubbles. If you leave the 2XROMM on ice, a precipitate can form. Before use, check if this has occurred. The precipitate can be re-dissolved by heating at $37^{\circ} \mathrm{C}$ for $\sim 5 \mathrm{~min}$ and pipette mixing.

22. If the protocol needs to be performed over two days, the ethanol precipitation in 3.4 is the safest overnight stopping point. After step 17 of 3.4.1 or step 24 of section 3.4.2, samples can be stored at $-80^{\circ} \mathrm{C}$. The protocol can also be stopped after the ethanol precipitation following TRIzol extractions, but samples must be stored for at most one night at $4{ }^{\circ} \mathrm{C}$ because at $-20^{\circ} \mathrm{C}$ precipitation of guanidinium salts can occur and interfere with enzymatic reactions. Alternatively, the RNA pellet can be stored at $-80^{\circ} \mathrm{C}$ after the precipitation and removal of the supernatant.

23. A blue pellet should be visible at the bottom of tube. The pellet can be difficult to see but should be visible. It may appear spread out. If a pellet is not visible, vortex well and repeat spin.

24. When removing the supernatant before the $70 \%$ ethanol wash be careful not to disturb the pellet. Approximately $30-50 \mu \mathrm{L}$ of ethanol can be left in the tube to avoid disturbing the pellet prior to adding the $70 \%$ ethanol wash. This procedure can also be used after the $70 \%$ ethanol wash, but then remove the final $30-50 \mu \mathrm{L}$ using a P200 tip after a quick spin in a picofuge. 
25. Air dry the RNA pellet by leaving tubes open in fume hood to prevent contamination. This will take $\sim 3-10$ min depending on how much ethanol is left in the tube. Do not to let the RNA pellet dry completely as this will greatly decrease its solubility.

26. When pipetting chloroform, always pipette twice because the first draw always leaks.

27. When transferring the aqueous phase of TRIzol extractions to a new tube, tilt the tube to a $45^{\circ}$ angle and carefully remove only the clear liquid. Avoid contamination by the pink organic phase or white interphase.

28. The concentration of RNA adapters in the ligation steps $(1 \mu \mathrm{L} 10 \mu \mathrm{M})$ is optimal for approximately $10^{6}$ mammalian cells. For lower cell numbers, the adapter concentration must be diluted to limit dimer formation. We dilute linearly with cell concentration relative to this established concentration, i.e. $1 \mu \mathrm{L} 5 \mu \mathrm{M}$ for $5 \times 10^{5}$ cells, $1 \mu \mathrm{L} 2.5 \mu \mathrm{M}$ for $2.5 \times 10^{5}$ cells, etc.

29. Pipette slowly because $50 \%$ PEG 8000 is very viscous. Heating $50 \%$ PEG8000 makes it easier to pipette. Pipette the ligation mix until it is homogenous before use.

30. When preparing enzymatic reaction mixtures that contain SUPERase-In RNase Inhibitor, a fixed volume ( $1 \mu \mathrm{L})$ SUPERase-In can be added to the entire master mix regardless of number of reactions to decrease cost. Bring the remainder of the master mix up to the required volume with DEPC $\mathrm{H}_{2} \mathrm{O}$. Murine RNase inhibitor can also be substituted to limit costs for all steps after the run-on. SUPERase-In is recommended prior to the run-on as it inhibits T1 RNase.

31. For each washing step gently invert tubes 10-15X, quickly spin down with a picofuge, open caps, and then place on the magnet stand. Wait 1-2 minutes and pipette the supernatant off without disturbing the beads. If there are bubbles in the tube carefully pipette them off first and then remove supernatant. Beware that bubbles may dislodge beads from the side of the tube. After removing the bulk of the liquid, collect remaining liquid with a quick spin in a picofuge, place the tube back on the magnet stand, and carefully remove remaining liquid by pipetting.

32. Transferring beads to a new tube after the binding incubation-during the high salt wash step-helps limit adapter dimer formation. After resuspending the beads in High Salt buffer, quickly spin down with a picofuge, resuspend beads by gently pipetting, and carefully transfer to a new tube. Pipette slowly to avoid bead loss! Place this new tube on the magnet stand and proceed with the washing protocol.

33. Do not allow streptavidin beads to dry completely, as this can lead to clumping and make full resuspension impossible. When processing multiple samples, remove liquid from the previous wash or enzymatic step from the first sample and 
immediately resuspend those beads in the next solution, then repeat this process for additional samples.

34. On-bead reaction volumes assume that $1 \mu \mathrm{L}$ of liquid remains on the beads.

35. Mix on-bead reactions by gently flicking the tubes every 10 minutes.

36. We have also successfully used Cap-Clip ${ }^{\mathrm{TM}}$ Acid Pyrophosphatase (CELLTREAT) instead of $\mathrm{RppH}$. Cap-Clip has lower buffer $\mathrm{pH}$ which may alleviate base hydrolysis of RNA that could occur in the pH 8.0 ThermoPol buffer. However, this is not a major concern except for in the most sensitive of applications.

37. Reverse transcription can also be performed on-bead, but we find that this significantly reduces library yield while increasing adapter dimer. For this reason, it is not recommended except in cases where material is abundant ( $10^{7}$ cells) and speed is paramount. To do this, follow steps 1-2 in section 3.12, then follow section 3.13, but resuspend the beads instead of the RNA pellet in RT resuspension mix. After $\mathrm{RT}$, elute cDNA by heating the bead mixture to $95^{\circ} \mathrm{C}$, quickly place tubes on a magnet stand, and remove and save supernatant. Resuspend beads in $20 \mu \mathrm{LddH_{2 }} \mathrm{O}$ and repeat the process for a final volume of 40 $\mu \mathrm{L}$. Proceed with PreCR but use $20 \mu \mathrm{L}$ less $\mathrm{ddH}_{2} \mathrm{O}(13.5 \mu \mathrm{L})$ in the PreCR mix and use the entire $40 \mu \mathrm{L}$ eluate instead of the $20 \mu \mathrm{L} \mathrm{RT}$ mix.

38. PreCR is optional if full scale amplification will be performed within 2 days. Longer storage of single-stranded cDNA libraries can lead to loss of library material. If you are skipping PreCR, simply store the $20 \mu \mathrm{L} \mathrm{RT}$ reaction at $-20^{\circ} \mathrm{C}$ overnight and perform test amplification the next day.

39. Because this protocol uses molecular barcodes (UMIs) which facilitate robust computational PCR deduplication, it is less important to precisely determine the optimal cycle number. We recommend performing test amplification the first time you perform this protocol with a given amount of material from a given cell line to determine the optimal cycle number. For future experiments where the material and cell number are constant, test amplification can be skipped. Adjust the volume of the full-scale PCR to $100 \mu \mathrm{L}$ total volume (accounting for the fact that the written protocol assumes loss due to test amplification). Test amplification can be performed either by PCR of a dilution curve and PAGE analysis or qPCR.

40. Do not attempt to scale down the PreCR or full-scale amplification steps to save PCR reagents. If RT reaction mixture exceeds $20 \%$ of the PCR reaction volume, significant inhibition of PCR will occur and lead to dramatically lower final library yield.

41. Taking $7.7 \mu \mathrm{L}$ of the $100 \mu \mathrm{L}$ PreCR reaction leaves $92.3 \mu \mathrm{L}$ for full-scale amplification. $25 \%$ of material in the first dilution is lost to make the next serial 4fold dilution $(2$ of $8 \mu \mathrm{L})$. Because $\left(7.7^{*} 0.75\right) / 92.3 \approx 1 / 16$, this first dilution is 
equivalent to the number of test amplification cycles less 4 . If starting from the RT reaction, the volume has been adjusted for 5-fold lower starting volume.

42. Additional cycles can vary by cell type. For HeLa, we typically perform 14 additional cycles (19 total cycles), which simulates 15 full-scale amplification cycles. For low input libraries (50k-250k mammalian cells), we typically perform 20 additional cycles (23 cycles total), which simulates 21 full-scale amplification cycles.

43. If PreCR was skipped, use an annealing temperature of $56^{\circ} \mathrm{C}$ for the first 5 cycles of test amplification and the full-scale amplification.

44. Desired amplification characteristics include a sufficient amount of product (smear starting 150 bp), no evidence of overamplification, and 50\% primer exhaustion (Mahat et al., 2016). The adaptor dimer product is $132 \mathrm{bp}$, and the smear will start 15-20 bp above this band. RNA degradation will lead to shorter library products.

45. AMPure XP beads will work, as will any commercially available or homemade SPRI bead cleanup reagent based on PEG precipitation. Be sure to allow beads to reach room temperature, or excess primers will also precipitate.

46. Due to advances in streptavidin bead technology and titration of adapters presented in this protocol, PAGE purification is rarely necessary. We prefer to sequence libraries that are 0\%-25\% adapter dimer rather than risk size bias associated with gel purification. Only perform PAGE purification if absolutely necessary. If needed, multiple libraries can be pooled by molarity as determined by bioanalyzer and extracted from the same gel lane to minimize size bias. 


\section{References}

Bentley DL, Groudine M. 1986. A block to elongation is largely responsible for decreased transcription of c-myc in differentiated HL60 cells. Nature 321:702-70. doi:10.1038/321702a0

Birse CE, Lee BA, Hansen K, Proudfoot NJ. 1997. Transcriptional termination signals for RNA polymerase II in fission yeast. EMBO J 16:3633-3643. doi:10.1093/emboj/16.12.3633

Blumberg A, Zhao Y, Huang Y-F, Dukler N, Rice EJ, Krumholz K, Danko CG, Siepel A. 2019. Characterizing RNA stability genome-wide through combined analysis of PRO-seq and RNA-seq data. bioRxiv. doi:10.1101/690644

Chu T, Rice EJ, Booth GT, Salamanca HH, Wang Z, Core LJ, Longo SL, Corona RJ, Chin LS, Lis JT, Kwak H, Danko CG. 2018. Chromatin run-on and sequencing maps the transcriptional regulatory landscape of glioblastoma multiforme. Nat Genet 50:1553-1564. doi:10.1038/s41588-018-0244-3

Churchman LS, Weissman JS. 2011. Nascent transcript sequencing visualizes transcription at nucleotide resolution. Nature 469:368-373. doi:10.1038/nature09652

Core LJ, Martins AL, Danko CG, Waters CT, Siepel A, Lis JT. 2014. Analysis of nascent RNA identifies a unified architecture of initiation regions at mammalian promoters and enhancers. Nat Genet 46:1311-20. doi:10.1038/ng.3142

Core LJ, Waterfall JJ, Lis JT. 2008. Nascent RNA sequencing reveals widespread pausing and divergent initiation at human promoters. Science 322:1845-1848.

doi:10.1126/science.1162228

Danko CG, Hah N, Luo X, Martins AL, Core L, Lis JT, Siepel A, Kraus WL. 2013. Signaling Pathways Differentially Affect RNA Polymerase II Initiation, Pausing, and Elongation Rate in Cells. Mol Cell 50:212-222. doi:10.1016/j.molcel.2013.02.015

Danko CG, Hyland SL, Core LJ, Martins AL, Waters CT, Lee HW, Cheung VG, Kraus WL, Lis JT, Siepel A. 2015. Identification of active transcriptional regulatory elements from GROseq data. Nat Methods 12:433-438. doi:doi:10.1038/nmeth.3329

Derman E, Krauter K, Walling L, Weinberger C, Ray M, Darnell JE. 1981. Transcriptional control in the production of liver-specific mRNAs. Cell 23:731-739. doi:10.1016/00928674(81)90436-0

Duarte FM, Fuda NJ, Mahat DB, Core LJ, Guertin MJ, Lis JT. 2016. Transcription factors GAF and HSF act at distinct regulatory steps to modulate stress-induced gene activation. Genes Dev 30:1731-1746. doi:10.1101/gad.284430.116

García-Martínez J, Aranda A, Pérez-Ortín JE. 2004. Genomic run-on evaluates transcription rates for all yeast genes and identifies gene regulatory mechanisms. Mol Cell 15:303-313. doi:10.1016/j.molcel.2004.06.004

Gariglio P, Bellard M, Chambon P. 1981. Clustering of RNA polymerase B molecules in the 5' moiety of the adult $\beta$-globin gene of hen erythrocytes. Nucleic Acids Res 9:2589-2598. 
doi:10.1093/nar/9.11.2589

Hirayoshi K, Lis JT. 1999. Nuclear run-on assays: Assessing transcription by measuring density of engaged RNA polymerases. Methods Enzymol 304:351-362. doi:10.1016/S0076-6879(99)04021-5

Jonkers I, Kwak H, Lis JT. 2014. Genome-wide dynamics of Pol II elongation and its interplay with promoter proximal pausing, chromatin, and exons. Elife 3:1-25. doi:10.7554/elife.02407

Kruesi WS, Core LJ, Waters CT, Lis JT, Meyer BJ. 2013. Condensin controls recruitment of RNA polymerase II to achieve nematode X-chromosome dosage compensation. Elife 2. doi:10.7554/eLife.00808

Kwak H. 2013. Dissection Of The Precise Mechanisms Of Rna Polymerase li Pausing And Elongation Using Nascent Transcript Analysis.

Kwak H, Fuda NJ, Core LJ, Lis JT. 2013. Precise maps of RNA polymerase reveal how promoters direct initiation and pausing. Science (80- ) 339:950-953. doi:10.1126/science.1229386

Mahat DB, Kwak H, Booth GT, Jonkers IH, Danko CG, Patel RK, Waters CT, Munson K, Core LJ, Lis JT. 2016. Base-pair-resolution genome-wide mapping of active RNA polymerases using precision nuclear run-on (PRO-seq). Nat Protoc 11:1455-1476. doi:10.1038/nprot.2016.086

Mahat DB., Salamanca HH, Duarte FM, Danko CG, Lis JT. 2016. Mammalian Heat Shock Response and Mechanisms Underlying Its Genome-wide Transcriptional Regulation. Mol Cell 62:63-78. doi:10.1016/j.molcel.2016.02.025

O'Brien T, Lis JT. 1993. Rapid changes in Drosophila transcription after an instantaneous heat shock. Mol Cell Biol 13:3456-3463. doi:10.1128/mcb.13.6.3456

Powell DJ, Friedman JM, Oulette AJ, Krauter KS, Darnell JE. 1984. Transcriptional and posttranscriptional control of specific messenger RNAs in adult and embryonic liver. J Mol Biol 179:21-35. doi:10.1016/0022-2836(84)90304-8

Rougvie AE, Lis JT. 1988. The RNA polymerase II molecule at the $5^{\prime}$ end of the uninduced hsp70 gene of D. melanogaster is transcriptionally engaged. Cell 54:795-804. doi:10.1016/S0092-8674(88)91087-2

Schwalb B, Michel M, Zacher B, Hauf KF, Demel C, Tresch A, Gagneur J, Cramer P. 2016. TTseq maps the human transient transcriptome. Science 352:1225-1228. doi:10.1126/science.aad9841

Vihervaara A, Mahat DB, Guertin MJ, Chu T, Danko CG, Lis JT, Sistonen L. 2017. Transcriptional response to stress is pre-wired by promoter and enhancer architecture. Nat Commun 8:255. doi:10.1038/s41467-017-00151-0

Wang Z, Chu T, Choate LA, Danko CG. 2019. Identification of regulatory elements from nascent transcription using dREG. Genome Res 29:293-303. doi:10.1101/gr.238279.118 
979 Weiss SB, Gladstone L. 1959. A Mammalian System for The Incorporation of Cytidine 980 Triphosphate into Ribonucleic Acid. J Am Chem Soc 81:4118-4119.

981 doi:10.1021/ja01524a087

982 Wissink EM, Vihervaara A, Tippens ND, Lis JT. 2019. Nascent RNA analyses: tracking 983 transcription and its regulation. Nat Rev Genet 20:705-723. doi:10.1038/s41576-019984 0159-6 
Table 1. Oligonucleotides

\begin{tabular}{|l|l|l|}
\hline Name & Sequence & Purification \\
\hline REV3 & /5Phos/rUrNrNrNrNrNNGATCGTCGGACTGTAGAACTCTGAAC/3InvdT/ & RNase-free HPLC \\
\hline REV5 & /5InvddT/CCTTGGCACCCGAGAATTCCANrNrNrNrNrNrC & RNase-free HPLC \\
\hline RP1 & AATGATACGGCGACCACCGAGATCTACACGTTCAGAGTTCTACAGTCCGA & PAGE \\
\hline RPI-1 & CAAGCAGAAGACGGCATACGAGATCGTGATGTGACTGGAGTTCCTTGGCACCCGAGAATTCCA & PAGE \\
\hline RPI-2 & CAAGCAGAAGACGGCATACGAGATAGATCGGTGACTGGAGTTCCTTGGCACCCGAGAATTCCA & PAGE \\
\hline RPI-3 & CAAGCAGAAGACGGCATACGAGATGCCTAAGTGACTGGAGTTCCTTGGCACCCGAGAATTCCA & PAGE \\
\hline RPI-4 & CAAGCAGAAGACGGCATACGAGATTGGTCAGTGACTGGAGTTCCTTGGCACCCGAGAATTCCA & PAGE \\
\hline RPI-5 & CAAGCAGAAGACGGCATACGAGATCACTGTGTGACTGGAGTTCCTTGGCACCCGAGAATTCCA & PAGE \\
\hline RPI-6 & CAAGCAGAAGACGGCATACGAGATATTGGCGTGACTGGAGTTCCTTGGCACCCGAGAATTCCA & PAGE \\
\hline RPI-7 & CAAGCAGAAGACGGCATACGAGATGATCTGGTGACTGGAGTTCCTTGGCACCCGAGAATTCCA & PAGE \\
\hline RPI-8 & CAAGCAGAAGACGGCATACGAGATTCAAGTGTGACTGGAGTTCCTTGGCACCCGAGAATTCCA & PAGE \\
\hline RPI-9 & CAAGCAGAAGACGGCATACGAGATCTGATCGTGACTGGAGTTCCTTGGCACCCGAGAATTCCA & PAGE \\
\hline RPI-10 & CAAGCAGAAGACGGCATACGAGATAAGCTAGTGACTGGAGTTCCTTGGCACCCGAGAATTCCA & PAGE \\
\hline RPI-11 & CAAGCAGAAGACGGCATACGAGATGTAGCCGTGACTGGAGTTCCTTGGCACCCGAGAATTCCA & PAGE \\
\hline RPI-12 & CAAGCAGAAGACGGCATACGAGATTACAAGGTGACTGGAGTTCCTTGGCACCCGAGAATTCCA & PAGE \\
\hline
\end{tabular}

